\title{
Л.В. Дериглазова
}

\section{ПАМЯТИ ЕЛЕНЫ ЮРЬЕВНЫ ЛИЦАРЕВОЙ, ПРОФЕССОРА ТОМСКОГО ГОСУДАРСТВЕННОГО УНИВЕРСИТЕТА}

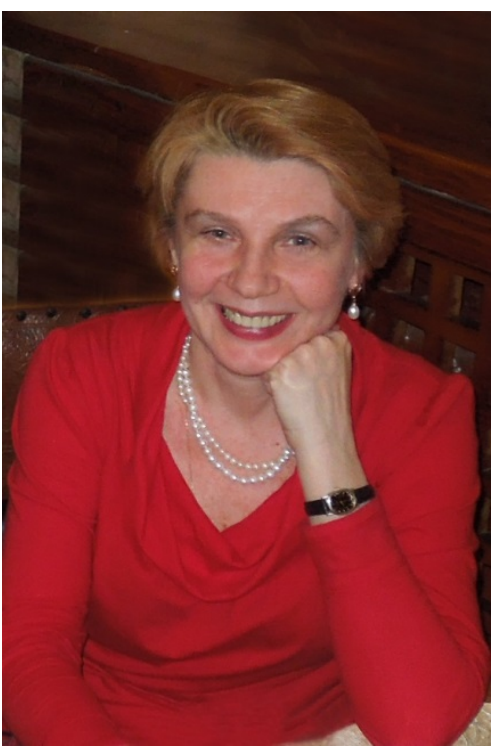

Эта статья составлена по материалам, посвященным Елене Юрьевне Лицаревой на сайте Электронной энциклопедии ТГУ, и воспоминаниям Савелия Вольфовича Вольфсона, доцента кафедры новой и новейшей истории и международных отношений ТГУ, знавшего Елену Юрьевну с детства. Для Савелия Вольфовича Елена Юрьевна была коллегой по кафедре и по работе на Отделении международных отношений, компонента по развитию востоковедения на факультете, а также активного сотрудничества вне университета - с органами власти, бизнеса, международными организациями и фондами.

Материалы подготовлены к печати Л.В. Дериглазовой, для которой Елена Юрьевна была коллегой на протяжении более 20 лет по кафедре мировой политики и надежным партнером в международных проектах.

Могу засвидетельствовать, что после извещения о безвременном уходе Елены Юрьевны 8 марта 2018 г., поступило большое количество телефонных звонков, электронных писем из разных городов России и разных стран от людей, которые знали Елену Юрьевну как преподавателя, ученого и человека. Все выражали глубочайшее потрясение случившимся и хотели выразить свое сочувствие близким и родным. Многие писали о том, что Елена Юрьевна останется в памяти как ученый и наставник, и еще как очень жизнерадостный и красивый человек. Многие знавшие Елену Юрьевну близко, отмечали ее мужество и стойкость в преодолении житейских проблем, ее оптимизм и умение справляться с трудностями, не посвящая в них других людей.

Опыт работы с Еленой Юрьевной на кафедре и в разных проектах показал мне, что она являлась глубоко порядочным человеком, далеким от интриг и сиюминутных интересов. Ее яркая внешность, умение общаться с разными людьми, в том числе далекими от университета, оригинальность мышления и чувство юмора привлекали к ней внимание и уважение. Ее путь в науке не был простым, несмотря на кажущуюся простоту. Ей приходилось преодолевать внутренние и внешние барьеры, предубеждения, отстаивать собственное место в науке, и она делала это часто не благодаря, а вопреки обстоятельствам. Работы Елены Юрьевны, посвященные экономическим аспектам международных отношений, останутся в науке. А для людей, знавших ее лично, остается глубочайшее сожаление о том, что было упущено и недосказано, и невозможность поверить в произошедшее.

Елена Юрьевна Лицарева (в дев. Индукаева) родилась 25 января 1961 г. в Томске в семье преподавателей Томского государственного университета. Отец, Юрий Васильевич Индукаев (1932-2015), окончил геологогеографический факультет Томского университета, защитил диссертацию и получил ступень кандидат геологоминералогических наук. Юрий Васильевич работал доцентом на кафедре минералогии и геохимии геологогеографического факультета ТГУ. Мать, Нина Семеновна Индукаева (в дев. Клубакова, 1935-2011), окончила ТГУ и прошла путь от лаборанта до доктора исторических наук, профессора кафедры новой, новейшей истории и международных отношений исторического факультета ТГУ.

Е.Ю. Лицарева окончила исторический факультет Томского государственного университета в 1983 г. по специальности «История» с присвоением квалификации «историк, преподаватель обществоведения». Среди ее университетских учителей - профессора С.С. Григорцевич, Н.С. Индукаева, доценты Б.С. Жигалов, С.В. Вольфсон, Т.А. Бычкова, Н.С. Черкасов и др. После окончания университета Е.Ю. Лицарева работала ассистентом кафедры истории КПСС Томского медицинского института (ныне Сибирский государственный медицинский университет). В 1986 г. поступила в аспирантуру по кафедре новой и новейшей истории исторического факультета Томского государственного университета. С 1988 г. работала старшим научным сотрудником Центра международных исследований ТГУ, с 1992 г. - старшим преподаватель кафедры новой, новейшей истории и международных отношений ТГУ, с 1996 г. - доцентом на кафедре теории международных отношений и организации внешнеполитической деятельности (ныне кафедра мировой политики) ТГУ, с 2007 г. - профессором кафедры мировой политики ТГУ. С 2015 г. Е.Ю. Лицарева занимала должность заведующей кафедрой востоковедения ТГУ, с 1996 г. Елена Юрьевна по совместительству работа на факультете международного управления (МФУ) ТГУ. 
Сфера научных интересов Елены Юрьевны включала вопросы экономических аспектов международных отношений. В 1980-е гг. областью научных интересов Е.Ю. Лицаревой была проблема военной задолженности европейских стран США, образовавшаяся в годы Первой мировой войны в результате военных поставок. Е.Ю. Лицарева сконцентрировала внимание на процессе выработки правящими кругами США политики в отношении Великобритании в период между Первой и Второй мировыми войнами в связи с выплатой военной задолженности. В 1988 г. в диссертационном совете при ТГУ Е.Ю. Лицарева защитила диссертацию «Проблема погашения военного долга Великобритании США в американо-английских отношениях (1922-1932 гг.)» на соискание ученой степени кандидата исторических наук (специальность 07.00 .03 - Всеобщая история; научный руководитель - доктор исторических наук, профессор С.С. Григорцевич, официальные оппоненты - доктор исторических наук, профессор В.П. Золотухин, кандидат исторических наук Я.А. Домбровский).

В начале 1990-х гг. Е.Ю. Лицарева занялась изучением истории международных экономических отношений и экономической интеграции стран Европейского союза и Азиатско-Тихоокеанского региона. Она выявила причины и сущность мирового интеграционного развития на примере Европейского союза и интеграционных образований в Азиатско-Тихоокеанском регионе, определила место экономической интеграции в этом процессе, проследила историю, выявила основные этапы, формы проявления и результаты экономической интеграции в рамках Европейского союза и Азиатско-Тихоокеанского региона, возрастающую роль экономической и валютной основы в процессе усиления взаимодействия, взаимопроникновения и взаимозависимости стран и народов, общие закономерности и специфические особенности экономических интеграционных процессов, перспективы и возможные варианты взаимодействия Российской Федерации с Европейским союзом и странами Азиатско-Тихоокеанского региона и интеграции России в глобальную систему экономических связей.

В 2006 г. в диссертационном совете при ТГУ Е.Ю. Лицарева защитила диссертацию «Политика стран Европейского Союза и Азиатско-Тихоокеанского региона в области экономической интеграции. Середина 1970-х гг. XX в. - конец $\mathrm{XX}$ века (историко-сравнительное исследование)» на соискание ученой степени доктора исторических наук (специальность 07.00.03 - Всеобщая история; научный консультант - доктор исторических наук, профессор В.П. Зиновьев; официальные оппоненты - доктор исторических наук, профессор С.Г. Лузянин, доктора исторических наук Г.Н. Новиков и С.В. Фоменко). В дальнейшем Е.Ю. Лицарева изучала проблемы стран Европы и АзиатскоТихоокеанского региона после кризиса 2008 г., инновационную политику и специализацию государств АзиатскоТихоокеанского региона.

Е.Ю. Лицарева - автор более 60 работ, в том числе 2 монографий и 5 учебных пособий. Елена Юрьевна принимала участие в работе ряда российских и международных конференций и симпозиумов. В их числе конференция «Будущее взаимодействия Европейского Союза и Восточной Европы» (Оксфорд, 2002); Международная конференция «Европейский союз и Россия: лицом к лицу» (Зальцбург, 2006); ежегодная встреча Ассоциации американских географов (Лас-Вегас, Невада, США, 2009); 12th International Conference «The Triple Helix and innovationbased economic growth: new frontiers and solutions» (Tomsk, 11-13 September 2014); Workshop grassroots innovation: prospects for the Triple Helix model (Chair) и др.

Е.Ю. Лицарева проходила стажировки в ведущих научных центрах России, Западной Европы, Соединенных Штатов Америки, Китайской Республике (Тайвань), Китая и Индии. В их числе программа Европейского банка реконструкции и развития «Подготовка команд менеджеров и консультантов для российских технопарков и малых инновационных фирм» (Ливерпуль, Великобритания, 1994); программа TASIS «Руководство человеческими ресурсами» (Гаага, Голландия; Копенгаген, Дания, 1996); программа Информационного агентства США «Проблемы будущего глобальных процессов» (Мэрилендский университет, США, 1996); стажировка в Московском государственном институте международных отношений в рамках проекта Института «Открытое общество» (фонд Сороса); программа «Поддержка кафедр» (2002); программа TEMPUS по европейским исследованиям (Оксфордский университет, Великобритания, 2000, 2001, 2002; Свободный университет Брюсселя, Бельгия, 2000, 2002); программа TEMPUS «Развитие сибирской сети европейских исследований» (Зальцбургский университет, Австрия, 2004, 2006); программа института аудиторов при Министерстве финансов Индии (Дели, 2004); инновационная образовательная программа Университета Фэн Цзя (Тайвань, 2007); программа двойного магистерского диплома по европейской интеграции EU TEMPUS-TASIS (Томский государственный университет, Россия; Свободный университет Брюсселя, Бельгия; 2007); Европейские исследования (Университет Кента, Великобритания, 2014) и др.

Елена Юрьевна принимала активное участие в жизни ТГУ и г. Томска. Она была членом диссертационного совета Д 212.267.03 по историческим наукам при Томском государственном университете (с 2007 г.), в 1999-2002 гг. - исполнительным директором Региональной общественной организации «Внешнеполитическая ассоциация», руководителем городской Школы молодого международника для учащихся 9-11-х классов. С 1996 г. Е.Ю. Лицарева входила в правление общественной организации «Томский маркетинг-клуб», с 2005 г. была активным членом Томского ротарианского клуба (Rotary club).

Е.Ю. Лицарева была награждена юбилейной медалью «400 лет городу Томску» (2004) и юбилейной медалью «70 лет Томской области» (2015). В 2012 г. ей было присвоено звание «Почетный работник высшего профессио- 
нального образования Российской Федерации». Елена юрьенва была дважды награждена премией ТГУ за высокие достижения в учебной деятельности.

\author{
С.В. Вольфсон
}

\title{
В ПАМЯТЬ О ЕЛЕНЕ ЮРЬЕВНЕ ЛИЦАРЕВОЙ
}

Лена... Елена Юрьевна Лицарева родилась в 1961 г., а в 1962 г. я поступил в аспирантуру при кафедре новой и новейшей истории исторического факультета ТГУ. На этой кафедре работала ее мама, Нина Семеновна Индукаева. Нина Семеновна была одной из первых учениц профессора Станислава Селиверстовича Григорцевича - фактического основателя кафедры. Именно при нем кафедра была первой к востоку от Москвы в нашей стране центром международных исследований, и прежде всего американистики. Американистом (и не только) был и С.С. Григорцевич, американистом была Н.С. Индукаева, американистом стала и Е.Ю. Лицарева.

Как-то так получалось у С.С. Григорцевича, что кафедра стала для нас своеобразным семейным очагом. Конечно, разногласия были, они не могли быть, но в любой ситуации сохранялось взаимное уважение. Как-то, сравнительно недавно, Лена напомнила мне, что я ее «носил на руках», когда она была маленькой. Да, это было. Мы наблюдали, как маленькая Лена росла, как закончила школу, как поступила к нам на исторический факультет, стала ученицей С.С. Григорцевича. Как ученица Станислава Селиверстовича стала сотрудницей «молодежной группы» (младшим научным сотрудником), успешно и вовремя защитила кандидатскую диссертацию.

Я как-то поверхностно относился к Лене в этот период. Для меня она еще оставалась веселой умной девушкой, оптимисткой. Я вместе с Ниной Семеновной любовался ею, когда она танцевала в хореографическом ансамбле университета, не пропускала веселые встречи факультета. И она была кандидатом исторических наук, серьезный исследователь, конечно, и в этом заслуга С.С. Григорцевича. Но всматриваясь в Лену в этот период более внимательно, я все более убеждался в ее честолюбии (я считаю это позитивное качество), работоспособности, целеустремленности.

И для меня не стало неожиданностью, что она защитила докторскую диссертацию по весьма сложной теме сравнения экономической интеграции в Западной Европе с интеграционными процессами в АзиатскоТихоокеанском регионе. Для работы по этой тематике требуются не только трудолюбие, но и большой кругозор и научная смелость. Становление Елены Юрьевны как доктора исторических наук совпало с серьезными поворотами в судьбах страны, университета, факультета: развал СССР, реформы 1990-х гг., трудное десятилетие в истории университета. Небольшой факт, отражающий проблемы того времени: рухнул потолок в конференц-зале главного корпуса... Чтобы выжить, выстоять, требовались инициатива, предприимчивость, смелость. Елена Юрьевна была среди инициативных и предприимчивых.

На историческом факультете открыли специальность «Международные отношения». При этом мы опирались на нашу - томскую - школу международных исследований. Елена Юрьевна первой поняла, что этого недостаточно и стала преподавать маркетинг. И не просто преподавать курс маркетинга студентам-международникам. Она первая на факультете поняла необходимость сотрудничества с деловыми людьми, с бизнесом. Я не раз убеждался лично, насколько была авторитетной Елена Юрьевна среди томских предпринимателей. Подчеркну вновь - в этом, как мы понимаем сейчас, очень важном деле, у нас на факультете Елена Юрьевна была первой. Нелегко перечислить, в каких мероприятиях, программах, деловых встречах она принимала участие. Но я хотел обратить внимание на факты, напрямую мало связанные с бизнесом.

Томский ротарианский клуб. Елена Юрьевна вступила в него более 10 лет тому назад. Пришла по приглашению на одно из его заседаний и осталась. Они принимала участие во всех мероприятиях и инициативах клуба, не уклонялась, когда речь шла о том, что нужно кому-то помочь. Но было у нее и свое дело. Общеобразовательная школа № 39 для детей с ограниченными возможностями. Каждый, полагаю, понимает, что это такое. Одно дело как-то по случаю посетить детей, принести подарки, другое - стремиться помогать, делать это в течение длительного времени (пока существовал клуб). Помню, какая радость была в клубе, когда Лена рассказала, что на фабрике в Туле можно приобрести баян, очень нужный школе, и как встречали в школе Елену Юрьевну и президента «Ротари-клуба» Евгения Борунова, когда они вручали этот баян учащимся и учителям.

Немало усилий и времени, средств (их надо было собрать) понадобилось, чтобы приобрести и подарить школе 33 «комплекта Монтессори», позволяющим учителям работать с детьми по современным методикам. Там, в «Ротари-клубе» я открыл для себя еще одно качество Елены Юрьевны - способность помогать людям, действовать активно и результативно. У меня создалось впечатление, что в последние годы Елена Юрьевна работала особенно активно, и по многим направлениям. В науке - принимала участие в международных конференциях в России и за рубежом, публикуя результаты своих научных изысканий, включая Китай. В учебной работе - принимала все новые обязательства и поручения, участвовала в разных проектах. И внешне выглядела весьма жизнерадостной. 
На деле все было гораздо сложнее, чем мы могли себе представить. Елена Юрьевна, как и ее мама Нина Семеновна Индукаева, была психологически уязвима. Очень переживала, когда встречалась с несправедливостью. Одна из подобных - это результат работы комиссии Рособрнадзора у нас на факультете. Удар, который был нанесен по кафедре востоковедения, формализм в бюрократической оболочке, приоритет бумаготворчества, нежелание считаться с реальными обстоятельствами глубоко ранят преподавателя и ученого. Мы не сумели уберечь Елену Юрьевну от подобных травм.

Вспоминая Елену Юрьевну Лицареву, сохраняя представление о ней как об умной и жизнерадостной женщине, я поражаюсь ее мужеству, особенно в последние годы, когда она болела, а мы об этом даже не подозревали. Профессор Елена Юрьевна Лицарева - неразрывная часть истории нашего факультета. В ней и останется.

Deriglazova Larisa V. (Tomsk State University). E-mail: dlarisa@inbox.ru

Volfson Saveliy $V$. (Tomsk State University). E-mail: volfson@dir.tsu.ru

IN MEMORY OF ELENA YURIEVNA LITSAREVA, PROFESSOR OF TOMSK STATE UNIVERSITY

Historians of Tomsk State University express their deep condolences on untimely death of Professor Elena Litsareva and inform about this event their colleagues in Russia and beyond. 